\title{
The Physicochemical Changes of Farm-Raised Pacific White Shrimp (Litopenaeus vannamei) as Influenced by Iced Storage
}

\author{
Charles Odilichukwu R. Okpala1,2 \\ ${ }^{1}$ School of Science, Monash University Sunway Campus, Bandar Sunway, Malaysia \\ ${ }^{2}$ Istituto per l'Ambiente Marino Costiero, Consiglio Nazionale delle Ricerche, Mazara del Vallo, Italy \\ Email: charlesokpala@gmail.com
}

Received 7 April 2015; accepted 21 July 2015; published 24 July 2015

Copyright (C) 2015 by author and Scientific Research Publishing Inc. This work is licensed under the Creative Commons Attribution International License (CC BY). http://creativecommons.org/licenses/by/4.0/

(c) (i) Open Access

\begin{abstract}
Farm-raised Pacific white shrimp (Litopenaeus vannamei) freshly harvested was evaluated for differences in proximal composition (moisture, ash, fat, and protein contents), water activity $\left(a_{w}\right)$, water retention index (WRI), $\mathrm{pH}$, colour and texture of up to 12 days of iced storage. Shortly after harvest, the proximate composition of shrimp appeared comparable across the farms. With ice storage, the $\mathrm{pH}$ significantly increased whereas fat content slowly decreased particularly between days 3 and $9(P<0.05)$, after which it stayed unchanged $(P>0.05)$. Expressly, the protein content of shrimp specimens gradually decreased after day $8(P<0.05)$. In addition, the moisture content, water retention index (WRI) and water activity $\left(a_{w}\right)$ of shrimp specimens exhibited inconsequential differences during iced storage. While the lightness $\left(L^{*}\right)$ was significantly affected from day 2 onwards, the yellowness $\left(b^{*}\right)$ colour was so but only between days 6 and $10(P<0.05)$. In addition, the adhesiveness and hardness textures of shrimp specimens registered peak values at day 11. Overall, the physicochemical differences in farm-raised shrimp during iced storage of this study provide valuable information for relevant stakeholders of the shrimp industry. Importantly, the data provided at this study can serve as baseline for comparison and evaluation of preservative treatments applied to shrimp.
\end{abstract}

\section{Keywords}

Litopenaeus vannamei, pH, Moisture, Colour, Adhesiveness, Hardness, Water Retention Index, Physicochemical Differences 


\section{Introduction}

Worldwide, shrimp are considerably sought for probably considering its high protein, low fat contents and cholesterol attributes. In the Western hemisphere, Pacific white shrimp (Litopenaeus vannamei) are important aquaculture species more commercially available over Penaeus monodon and Penaeus chinensis [1]-[6]. Food and Agricultural Organization (FAO) reported the global production of L. vannamei has exceeded 1,000,000 tons by 2004 exceeding that of $P$. monodon [7]. Ma et al. [8] reported that global production of $L$. vannamei had reached 2,328,000 tons equalling a profit of 9218 million US dollars. In Mexico, it represents greater than 70\% of aquaculture production and the revenue provides over $80 \%$ of total economic aquaculture resource to the population [9]. It has been shown that the sensory quality of many products, particularly flesh foods actually improve for short periods of time post-mortem. However, the quality of shrimp obtained immediately after harvest is recommended for consumption, as it is healthier compared with during post-mortem storage where it undergoes physicochemical deteriorations [10]-[13].

Many studies concerning the characteristics properties of shrimp that were subject to range of preservative treatments have been reported elsewhere [3]-[5] [12]-[19]. Typically, the breakdown of fat and protein are important stages of decomposition observed in fishery products that are kept either chilled or frozen [14] [15] [18]. The differences in moisture and water activity $\left(a_{w}\right)$ of shrimp may reflect the freshness as well as the degree to which it is subject to degenerate [17]. The water-holding capacity (WHC) plays an important role in the determination of the physical property of shrimp such as texture. In addition, the colour and texture can partially depend on the WHC [20]. While the reduction in WRI suggests a greater release of less "free" water and thus, an increase in WHC of the shrimp meat [21], other researchers have demonstrated the significance of physical attributes such as colour and texture during shrimp processing [19] [22]. Further, ice is widely accepted as means to chill foodstuff as it is poised to cool faster than refrigeration. If well distributed, the ice shows potential to uniformly impact on food products [16]. Previous researchers have shown that applying ice directly after catch could fast chill the shrimp and result in the lessening of formation of nitrogenous compounds as well as holding-up pH increases of fishery products [19] [23]. In addition, the quality and shelflife of untreated shrimp freshly harvested and stored on ice was recently investigated. Apart from the fact that a baseline investigation of shelflife and quality of shrimp is useful to supplement existing information, it is imperative to quantify the quality and shelflife of the untreated shrimp prior to application of preservative treatments [2]. Nonetheless, considering the increase in demand of fishery products globally [24] as well as existing scientific literature about raw and processed shrimp, there is still paucity of information concerning physicochemical differences of untreated Pacific white shrimp during cold storage.

Therefore, it was of interest to investigate how iced storage would influence the physicochemical properties of farm-raised Pacific white shrimp (L. vannamei) freshly harvested from three different farms.

\section{Materials and Methods}

\subsection{Collection of Shrimp Specimens}

The $L$. vannamei shrimp used for this study were of between 60 and 80 shrimp/kg and harvested from three different farms in Selangor, Peninsular Malaysia. The three shrimp farms identified as Farms A, B and C because permission was not given to indicate the names of the farms, was no more than $5 \mathrm{~km}$ apart. A total of $30 \mathrm{~kg}$ of shrimp were used for the study (10 kg per batch $\times 3$ farms). The harvest of shrimp was done by cast net, which was considered to provide a random sample. The shrimp with signs of visual defects or breakage were removed. It is considered the samples are representative of shrimp harvested in the region.

\subsection{Experimental Program and Study Design}

The schematic overview of the experimental program is presented in Figure 1. The design of this study was adapted from previous research [2] and modified slightly to investigate the physico-chemical differences of untreated Pacific white shrimp during iced storage. Immediately after harvest, the live shrimp were washed using clean flowing water and thereafter placed in sterile Reynolds ${ }^{\circledR}$ zipper $(26.8 \times 27.9 \mathrm{~cm})$ polyethylene bags $(\mathrm{Al}-$ coa Products Inc., Richmond, VA, USA). Then, the shrimp were arranged uniformly in styrofoam boxes between layers of ice at a shrimp/ice ratio of $1: 2(\mathrm{w} / \mathrm{w})$ and transported to the laboratory within approximately $2 \mathrm{~h}$. 


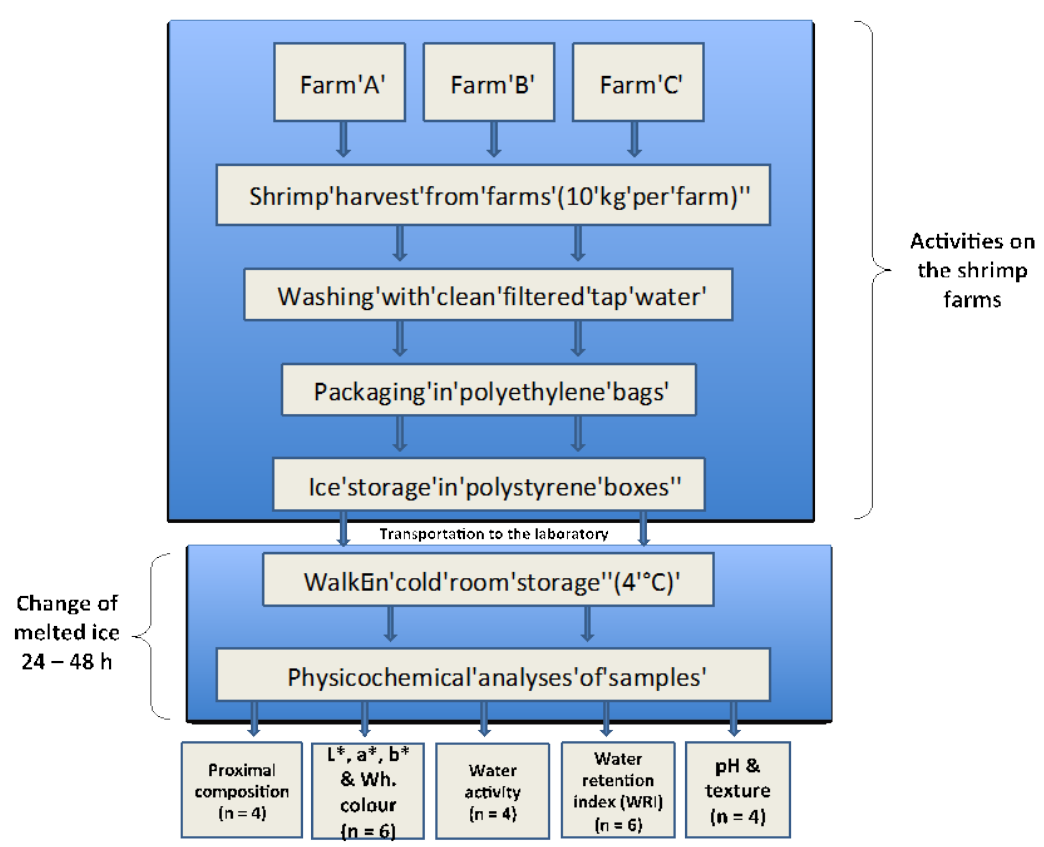

Figure 1. The schematic overview of the experimental study; The proximal composition refers to moisture, fat, protein, and ash contents; The Wh. refers to whiteness; The " $n$ " refers to number of replicates of different shrimp samples independent of farm.

Upon arrival the ice-packed shrimp boxes were kept in a walk-in cold room $\left(\sim 4^{\circ} \mathrm{C}\right)$ until required for analyses. Prior to all the analyses, the shrimp were beheaded, peeled and deveined by hand. Time zero was taken as the day of harvest. With the exception of the determination of fat content that began no more than $6 \mathrm{~h}$ after harvest, all other experimental analyses were carried out at intervals of no more than two days for up to 12 days. Per batch, approximately $200 \mathrm{~g}$ shrimp (that is, between 14 and 17 shrimp) were contained per polyethylene pack. For each day of laboratory analyses, two to three packs per batch were used from which the data of the present study was generated. Thereafter, the data representing each farm (Farm A, B and C) were pooled together ( $\mathrm{n}=3$, where three represented the total number of farms sampled). All chemicals used in the present study were of analytical grade. Unless otherwise indicated, all analyses were repeated four times on different shrimp specimens.

\subsection{Physico-Chemical Analyses}

\subsubsection{Proximate Measurements}

Proximal compositions, expressed in $\mathrm{g} / \mathrm{kg}$ (ash, fat, moisture and protein contents), were carried out on shrimp samples on a wet weight basis. To determine moisture content, approximately $10 \mathrm{~g}$ of shrimp meat were placed in a vacuum oven (Memmert ${ }^{\circledR}, \mathrm{D} 91107$ Schwabach, Germany) and heated at $105^{\circ} \mathrm{C} \pm 2^{\circ} \mathrm{C}$ overnight $(18-24 \mathrm{~h})$ and cooled to ambient temperature (desiccators) until it achieved constant weight [25]. The fat content of shrimp samples was assayed using the Werner-Schmidt Process [25]. This was done using approximately $2 \mathrm{~g}$ of shrimp meat homogenized with $\mathrm{HCl}$, then water bath heated $\left(\sim 80^{\circ} \mathrm{C}\right)$ for $\sim 5 \mathrm{~min}$. After it cooled, alcohol and diethyl ether is applied and vortexed briefly for fat separation, then total fat measured by weight difference after drying at $\sim 30^{\circ} \mathrm{C}$ [25]. Nitrogen content was determined by AOAC Official Method 928.08 (Kjeldahl Method) [26] using conversion factor of 6.25 to calculate protein content [25]. Ash content was determined by AOAC Official Method 920.153 using furnace at $550^{\circ} \mathrm{C}$ [26].

\subsubsection{Determination of $\mathrm{pH}$}

The $\mathrm{pH}$ measurements were carried out using a $\mathrm{pH}$ Meter (SevenGo Duo ${ }^{\mathrm{TM}}$, Mettler-Toledo Inc., Columbus, OH 43240, USA). Approximately $20 \mathrm{~g}$ of whole shrimp was homogenised using a blender with $80 \mathrm{~mL}$ distilled water (Waring Pro ${ }^{\circledR}$, Waring Laboratory Science, Winsted, CT, USA). The $\mathrm{pH}$ Meter probe was calibrated with standard buffer at $\mathrm{pH} 4.0$ prior to use [4]. 


\subsubsection{Determination of Water Activity}

Water activity $\left(a_{w}\right)$ was determined on $\sim 3$ g of shrimp meat using a water activity meter (AquaLab Model 4TE, Decagon Devices Inc., Pullman, WA, USA). Prior to $\mathrm{a}_{\mathrm{w}}$ measurements, samples were placed in a disposable cup supplied by the manufacturer that was then placed in the water activity instrument, which was then sealed with the sample chamber lid [4]. The $a_{w}$ was carried out six times on different shrimp samples from each of the bags per farm per day of analysis.

\subsubsection{Determination of Colour Attributes}

The colour measurements were carried out using the Hunter $L, a$, and $b$ scales, according to the method of Arfat and Benjakul [27] with slight modifications to evaluate the surface of shrimp samples. All colour determinations were carried out six times on different shrimp samples. The colormeter (Hunterlab ColorFlex®, Hunter Associates Laboratory Inc., Reston, VA, USA) employed was calibrated first with a black standard followed by a white standard to obtain the final setting, both placed centrally over the sample port. The dressed shrimp meat ( $\sim 5-7 \mathrm{~g}$ ) was placed in an optically clear glass cup, which was placed on the port and covered with an opaque cup cover. The glass cup had sufficient space to contain the dressed shrimp sample while totally covering the bottom surface. The opaque cup cover whilst accommodating the shrimp sample contained, it excluded any external light interference. Using the Hunter $L^{*}, a^{*}$, and $b^{*}$ scale, $L^{*}$ represents lightness on the scale of 0 (dark) to 100 (white); $+a^{*}$ for redness and $-a^{*}$ for greenness; and $+b^{*}$ for yellowness and $-b^{*}$ for blueness. According to Schanda [28], whiteness colour indicates the degree by which a given surface is white and should not be confused with lightness, which depicted the scale from light to dark of a given specimen. For that reason, the whiteness $(\mathrm{W})$ colour of the shrimp was determined from the commonly used equation below:

$$
\text { Whiteness }(W)=100-\sqrt{\left[\left(100-L^{*}\right)^{2}+a^{*^{2}}+b^{*^{2}}\right]}
$$

\subsubsection{Determination of Water Retention Index (WRI)}

To determine the water retention index (WRI), the filter paper press method as previously described by Lin and Chao [21] that was modified by Okpala [4] was applied to the shrimp samples (Figure 2). The amounts of expressed or "free water" can be estimated [29]. Approximately $2 \mathrm{~g}$ of dressed shrimp meat was placed on Qualitative Circles ${ }^{\circledR}$ filter paper (125 mm diameter) (GE Healthcare, Buckinghamshire, UK) on a clean IKEA white chopping board ( 1/4 inch thick) (IKEA Damansara, Malaysia) (Step 1) and another filter paper was placed on top of the sample. The plastic white surface was selected because it is tough and capable to withstand hand press pressure required to achieve this procedure as well as to ensure the clarity of view of the emerging wet filter paper and meat spread thereafter. A stainless steel weight of $2 \mathrm{~kg}$ was placed on the filter paper and rapidly pressed by hand (between $5-10 \mathrm{sec}$ ) until mince had become as flat as possible. The press time thereafter was 3 min (Step 2) after which the stainless steel weight of $2 \mathrm{~kg}$ was carefully removed (Step 3). The filter paper on top and below the shrimp enabled an even spread of the mince. The press time was previously estimated during a pilot study to show that the results were consistent and in agreement with that of Lin and Chao [21] and Lin and Keeton [29]. All these steps are shown in Figure 2.

After the weight was removed, the wet and meat area could be observed physically without any difficulty. Lin and Chao [21] used a planimeter to measure the spread of the meat and wet areas on the filter paper. Repeated trials of this procedure during the pilot study consistently gave an almost spherical-like shape for both the wet filter paper and the meat spreads on the filter paper as can be seen at Step 3 of Figure 2. Therefore, in the absence of a planimeter and given the consistently spherical-like shaped wet spot on the filter paper and meat spreading, the formula for the area of a sphere was deemed an appropriate and simple method to use to estimate the wet filter paper and meat areas:

$$
\text { Area (wet paper or meat area)(measured in } \mathrm{mm})=4 \times \pi \times r^{2}
$$

where $\pi=22 / 7$, and $r$ is the radius. Measuring four diameter lines and recording the radii, the area was calculated. This was done independently for the meat and wet spreads. The water retention index (WRI) is expressed as a ratio between the wet and meat spread areas. The WRI was carried out six times on different shrimp samples obtained per farm after which the data was pooled together. 


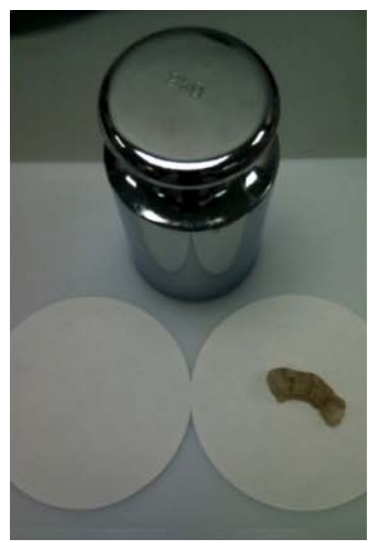

Step 1

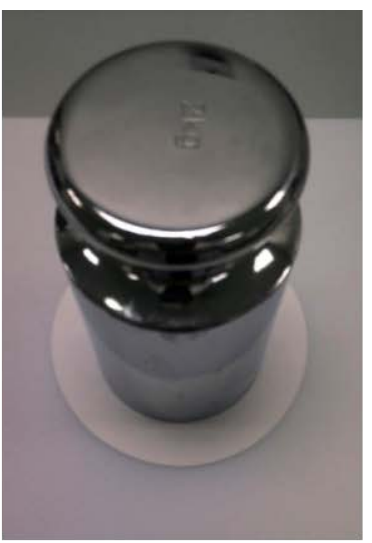

Step 2

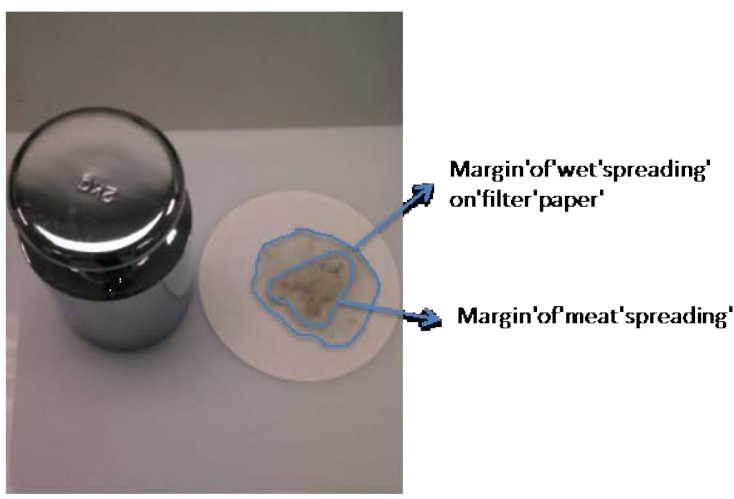

Step 3

\begin{abstract}
Figure 2. The determination of water retention index (WRI) using the filter paper press method according to Lin and Chao [21] slightly modified and reported by Okpala [4]. Step 1 shows the dressed shrimp meat placed on a filter paper, the stainless steel weight of $2 \mathrm{~kg}$ beside and all kept on a plane white surface. The next step shows the hand-pressed stainless steel weight of $2 \mathrm{~kg}$ on the filter paper with the shrimp sample underneath. After a press time of 3 min, the margins of the wet and meat spread are observed (depicted with the traced lines) as shown in Step 3.
\end{abstract}

\title{
2.3.6. Determination of Texture Attributes
}

The texture of shrimp samples was measured using a texture analyzer (TA.XT. plus ${ }^{\circledR}$, Stable Micro Systems, Surrey, Godalming, UK) equipped with a stainless steel needle probe. The parameters for the automatically operating compression test mode were movement at the rate of $2 \mathrm{~mm} \cdot \mathrm{s}^{-1}$ using a $5 \mathrm{~kg}$ cell load capacity. The dressed shrimp samples were placed on the test bed and the position limit was set at a level that would assure sufficient space within the sample test area. After probe test had completed and with the help of texture profile analyses (TPA) graph, the hardness, fracturability and adhesiveness textures (all expressed in Newton second [N.s]) were determined [30]. The Texture Exponent (TEE software version 4 for Windows, Stable Micro Systems Ltd., Surrey, UK) is software that enables the calculation of TPA outcomes and this was used to process the data [31] [32].

\subsection{Statistical Analysis}

Statistical analysis was applied using one-way analysis of variance (ANOVA) for all data.While the means and standard deviations (SD) were determined, differences between the means were resolved, by post-hoc, usingTukey's Honestly Significant Difference (HSD). Level of significance was defined at $P<0.05$ [2] [3]. 


\section{Results and Discussion}

For emphasis, the measurements carried out in the present study included proximal composition (ash, fat, moisture, ash, fat, and protein contents), water activity $\left(a_{w}\right)$, water retention index (WRI), pH, colour and texture of shrimp from these farms for up to 12 days.

\subsection{Initial Proximal Composition, pH, Colour, Water Activity, Water Retention Index, and Fracturability of Pacific White Shrimp Freshly Harvested from Different Farms}

The feed fed to farm-raised shrimp could strongly influence the proximal composition. Usually, fish products are considered to be of higher quality between the end of the main feeding season and the initial stages of gonad development, as well as at their poorest condition just after spawning. In addition, the feeding season could influence their characteristic properties [24]. Table 1 presents the initial proximate composition, pH, colour, WRI, water activity and texture parameters of the Pacific white shrimp freshly harvested from different farms. Generally, the initial proximate composition of freshly harvested shrimp showed very minor differences across the farms. This initial proximate composition of Pacific white shrimp could therefore be compared with other similar shrimp species such as black tiger shrimp ( . monodon) and white shrimp ( $P$. vannamei) previously reported by Sriket et al. [33], Cao et al. [34] as well as Nirmal and Benjakul [13]. Shortly after harvest, there was no difference in initial moisture and protein contents, as well as $a^{*}$ colour value and water activity $\left(a_{w}\right)$ of shrimp between the farms of this study $(P>0.05)$. Specifically, the initial moisture contents ranged between $76.379 \pm$ 0.793 and $77.042 \pm 0.949 \mathrm{~g} / \mathrm{kg}$ whereas protein contents ranged between $18.041 \pm 0.432$ and $18.249 \pm 0.432$ $\mathrm{g} / \mathrm{kg}$ across the farms. The results are comparable to moisture (77.21\%) and protein contents (18.8\%) of Thailand farm-raised Pacific white shrimp reported by Sriket et al. [33]. The Pacific white shrimp reported by Nirmal and Benjakul [13] farmed in Thailand had 13.4\% protein which seems below the initial protein content of the present study. Also, the species and variety, state of nutrition, reproductive cycle of specimen as well as parts of organism are useful candidates capable of affecting the protein content of any given fishery product [35].

Across the farms, the initial fat and ash contents, $\mathrm{pH}$, the $L^{*}, b^{*}$ and whiteness colour values, water retention index (WRI), as well as fracturability of fresh Pacific white shrimp showed considerable differences $(P<0.05)$. Specifically, the fat content ranged between $1.203 \pm 0.001$ and $1.239 \pm 0.026 \mathrm{~g} / \mathrm{kg}$ whereas the ash content

Table 1. Initial proximate composition, $\mathrm{pH}$, colour, water components and texture of Pacific white shrimp (L. vannamei) freshly harvested from different farms.

\begin{tabular}{|c|c|c|c|}
\hline \multirow{2}{*}{ Parameters } & \multicolumn{3}{|c|}{ Pacific white shrimp (L. vannamei) } \\
\hline & Farm A & Farm B & Farm C \\
\hline Moisture (g/kg) & $76.971 \pm 1.540^{\mathrm{a}}$ & $77.042 \pm 0.949^{\mathrm{a}}$ & $76.379 \pm 0.793^{\mathrm{a}}$ \\
\hline Protein $(\mathrm{g} / \mathrm{kg})$ & $18.197 \pm 0.601^{\mathrm{a}}$ & $18.041 \pm 0.432^{\mathrm{a}}$ & $18.248 \pm 0.432^{\mathrm{a}}$ \\
\hline Fat $(\mathrm{g} / \mathrm{kg})$ & $1.203 \pm 0.001^{\mathrm{b}}$ & $1.239 \pm 0.026^{\mathrm{a}}$ & $1.209 \pm 0.034^{\mathrm{b}}$ \\
\hline Ash (g/kg) & $2.072 \mathrm{a} \pm 0.051^{\mathrm{a}}$ & $2.022 \pm 0.214^{\mathrm{a}}$ & $1.783 \pm 0.498^{\mathrm{b}}$ \\
\hline $\mathrm{pH}$ & $6.771 \pm 0.148^{\mathrm{b}}$ & $6.723 \pm 0.009^{c}$ & $6.802 \pm 0.018^{\mathrm{a}}$ \\
\hline$L^{*}$ & $27.021 \pm 4.118^{\mathrm{b}}$ & $32.428 \pm 3.318^{\mathrm{a}}$ & $33.961 \pm 2.972^{\mathrm{a}}$ \\
\hline$a^{*}$ & $-1.288 \pm 0.459^{\mathrm{a}}$ & $-0.480 \pm 0.690^{\mathrm{a}}$ & $-0.662 \pm 0.824^{\mathrm{a}}$ \\
\hline$b^{*}$ & $2.589 \pm 0.790^{\mathrm{b}}$ & $2.790 \pm 0.481^{\mathrm{ab}}$ & $3.903 \pm 1.389^{\mathrm{a}}$ \\
\hline Whiteness & $27.201 \pm 4.472^{\mathrm{b}}$ & $31.362 \pm 3.099^{\mathrm{ab}}$ & $34.553 \pm 2.102^{\mathrm{a}}$ \\
\hline WRI & $1.544 \pm 0.461^{\mathrm{a}}$ & $1.392 \pm 0.165^{\mathrm{ab}}$ & $1.103 \pm 0.047^{\mathrm{b}}$ \\
\hline Water activity $\left(\mathrm{a}_{\mathrm{w}}\right)$ & $0.901 \pm 0.041^{\mathrm{a}}$ & $0.902 \pm 0.034^{\mathrm{a}}$ & $0.917 \pm 0.024^{\mathrm{a}}$ \\
\hline Fracturability (Ns) & $0.162 \pm 0.033^{\mathrm{b}}$ & $0.301 \pm 0.139^{\mathrm{a}}$ & $0.110 \pm 0.034^{\mathrm{b}}$ \\
\hline
\end{tabular}

Different letters (a, b, c) in the same row indicate the significant differences $(P<0.05)$; Moisture, protein, fat and ash expressed on wet weight basis; WRI = Water Retention Index; Values presented as means \pm standard deviation (Refer to Figure 1 for the number of replicates during respective analysis). 
ranged between $1.783 \pm 0.498$ and $2.072 \pm 0.051 \mathrm{~g} / \mathrm{kg}$. The fat and ash result were respectively below the $\sim 1.30 \%$ of fat and above the $\sim 1.47 \%$ of ash content values previously reported by Sriket et al. [33]. At the beginning of cold storage, fishery products of good condition usually show relatively low $\mathrm{pH}$ and this is understood to reflect the degree of freshness [36]. In the present study, the initial $\mathrm{pH}$ of fresh Pacific white shrimp across farms ranged between $6.723 \pm 0.009$ and $6.802 \pm 0.018$, which fell below the initial $\mathrm{pH}$ of 7 of untreated farmed Pacific white shrimp recently reported by Mu et al. [37]. The initial $L^{*}, b^{*}$ and whiteness colour values in the present study ranged between $27.021 \pm 4.118$ (Farm A) and $33.961 \pm 2.972$ (Farm C), $2.589 \pm 0.790$ (Farm A) and $3.903 \pm 1.389$ (Farm C) as well as $27.201 \pm 4.472$ (Farm A) and $34.553 \pm 2.102$ (Farm C), respectively. Generally, the initial colour values obtained at the present study are comparable to the values of other shrimp species (harvested as wild and non-targeted species) previously reported by Eid et al. [38]. Across the farms, the water retention index (WRI) of shrimp ranged between $1.103 \pm 0.047$ and $1.544 \pm 0.461(P<0.05)$. The result suggested that the WRI of shrimp might differ among similar species obtained from different harvest locations. Additionally, the fracturability ranged between $0.110 \pm 0.034$ and $0.301 \pm 0.139$ N.s and this might resemble the texture data reported by Tsironi et al. [39] where shrimp prior to iced storage showed some form of elastic and firm texture.

\subsection{Changes in pH during Iced Storage}

The $\mathrm{pH}$ of $L$. vannamei shrimp significantly increased during iced storage of 12 days $(P<0.05)$ (Figure 3$)$ in agreement with the behaviour of $\mathrm{pH}$ of white shrimp previously reported by Nirmal and Benjakul [12]. Generally, $\mathrm{pH}$ of fresh fishery products range between 6.0 and 6.5 and often show increases during cold storage [40] but as the present study tends to suggest this occurrence may not be consistently so for all fishery products. In addition, the action of enzymes to produce ammonia and other amines could cause the $\mathrm{pH}$ to increase in shrimp during ice storage [41]. Nevertheless, microbial processes may also be involved with the accumulation of alkaline metabolites that could affect the $\mathrm{pH}$ [42].

\subsection{Changes in Fat and Protein Contents during Iced Storage}

Seasonal changes, the feed fed to fishery products as well as degree/stage of maturity are believed to influence the fat content of fishery product [24]. In L. vannamei shrimp particularly within the first three days of iced storage of this study, the fat contents of showed no statistical difference $(P>0.05)$. Thereafter, fat gradually decreased up to day $9(P<0.05)$ after which it stayed unchanged $(P>0.05)$ (Figure 4). Some authors believe that ice contributes to the breakdown of fat [14] [18]. During the first 8 days of ice storage of the present study, the protein content of $L$. vannamei shrimp showed no statistical differences $(P>0.05)$. Thereafter, there appeared a

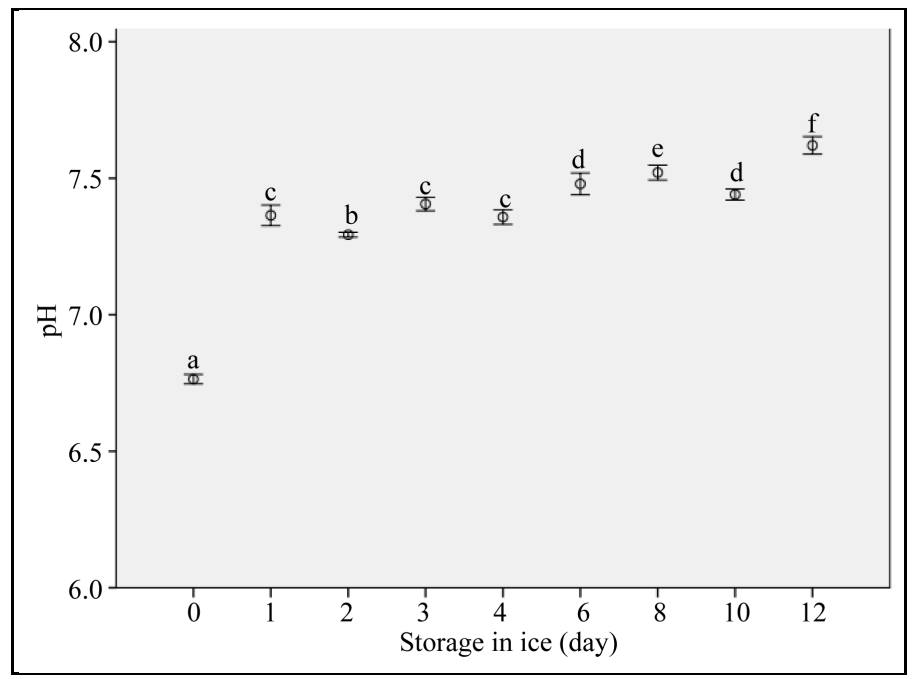

Figure 3. Changes in $\mathrm{pH}$ of Pacific white shrimp during 12 days of iced storage. Different letters indicate significant difference $(P<0.05)$. Bars represent standard deviations $(n=3)$. 


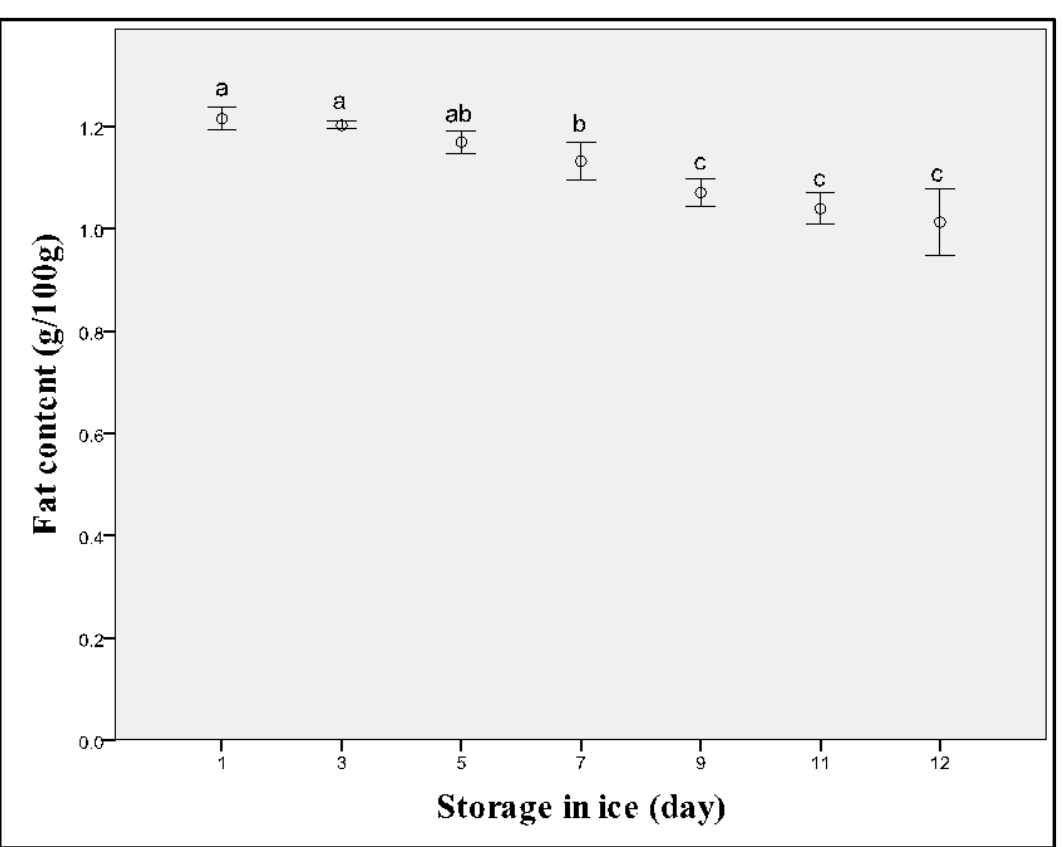

Figure 4. Changes in fat content of Pacific white shrimp during 12 days of iced storage. Different letters indicate significant difference $(P<0.05)$. Bars represent standard deviations $(n=3)$.

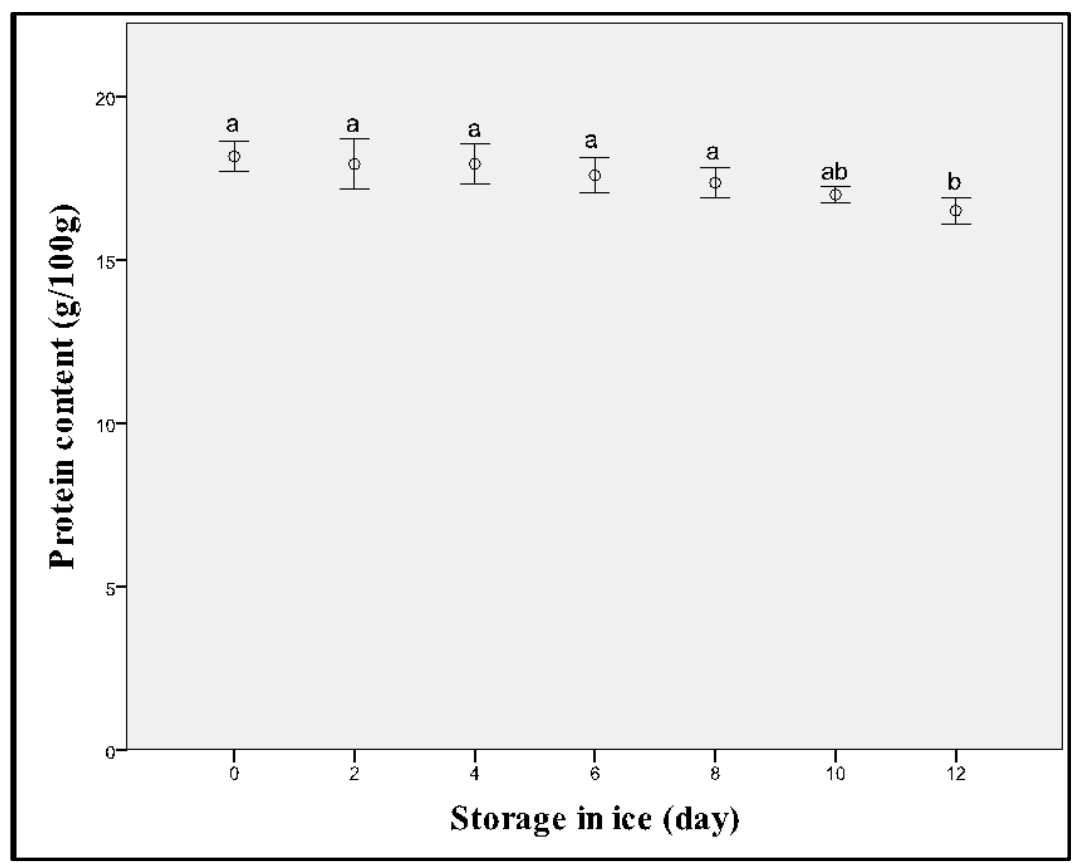

Figure 5. Changes in protein contents of Pacific white shrimp during 12 days of iced storage. Different letters indicate significant difference $(P<0.05)$. Bars represent standard deviations $(n=3)$.

gradual decrease in protein content of shrimp $(P<0.05)$ (Figure 5). This gradual decrease in protein of shrimp here shown could be associated with the decrease in the available amino acids as reported by Fatima et al. [15]. It is also understood that the muscle of shrimp possess thick (myosin) and thin (actin) filaments linked by connective tissues (stroma). For this reason therefore, quantities of moisture might be held between the myofibrillar 
spaces. During iced storage however, protein contents might then aggregate and result in the formation of filament lattice up to the subsequent gradual shrinking of the collagen [19]. In addition, the break down of protein into trimethylamine oxide that reduces to trimethylamine may result in the emission of ammonia [25].

\subsection{Changes in Moisture Content during Iced Storage}

Generally, moisture has been an important factor in food quality, preservation and could play a role with regards to resistance to deterioration of foods [43]. In the present study, differences in moisture content of L. vannamei shrimp were inconsequential throughout ice storage. The moisture content ranged between $75.13 \pm 0.46$ and $76.79 \pm 0.98 \mathrm{~g} / \mathrm{kg}$ (Figure 6(a)). The result can be compared with the moisture differences that were reported by Huidobro et al. [23] concerning iced-stored deep water pink shrimp that were processed on-board a ship. These authors indicated that the moisture content of shrimp from day 1 up to 4 ranged between either $76.10 \%$ and $77.10 \%$ or $77.10 \%$ and $77.50 \%$ when kept on flake and liquid ice, respectively. It was after $24 \mathrm{~h}$ as well as after day 4 of chilled storage, that minor increases in moisture content was found for the shrimp that were kept on liquid ice [23]. Other authors believed that the fish caught either during or after spawning could exhibit increases in moisture content, yet would be relatively low in lipid and protein contents, compared with those caught during the intense feeding periods [24].

\subsection{Changes in Water Activity $\left(a_{w}\right)$ during Iced Storage}

It has been argued that moisture content alone is not reliable and sufficient food quality indicator considering the differences occurring between associations of water with other food constituents. In addition, when tightly bound with other food constituents, water is less available for microbial growth and biochemical decomposition [43]. According to Richardson and Finley [44], water activity is able to influence the oxidation of fresh foods particularly during storage. In addition, the water activity of any given food system is an important index worthy to consider particularly because of the resultant chemical effects during food processing. Although the differences in temperature may have a somewhat pronounced effect on the water activity of food products, it is very likely to be of little significance in most food storage situations. Other researchers reported that both aerobic and anaerobic degradation reactions are able to increase exponentially between low and intermediate moisture of food and model systems when the water activity range between $\sim 0.1$ and 0.8 [44]. Nonetheless, the water activity $\left(a_{w}\right)$ might be an indicator of choice with regards to food perishability [43]. In the present study, no difference in $a_{w}$ of $L$. vannamei shrimp occurred particularly during the first four days of iced storage $(P>0.05)$. Thereafter, $a_{w}$ fluctuated significantly reaching a peak of $0.97 \pm 0.01$ at day $10(P<0.05)$ (Figure $6(\mathrm{~b})$ ). The high water activity recorded at this study might be attributable to the direct impact of ice in exerting its influence towards the shelf of the shrimp of this study. A high $\mathrm{a}_{\mathrm{w}}$ is understood to potentially hinder the growth of microorganisms that could be harmful on shrimp products [17].

\subsection{Changes in Water Retention Index (WRI) during Iced Storage}

During the first four days of ice storage, the water retention index (WRI) of L. vannamei shrimp fluctuated some- what widely but with an overall decreasing trend. Particularly from day 6 until the end of storage the WRI remained unchanged $(P>0.05)$ (Figure 6(c)). The results suggests a slight initial decrease in WRI of shrimp, which might depict that the amount of water the shrimp could hold tight enough might not be involved in syneresis. Further, the decrease in WRI might be associated with the overall reduction in protein reactive groups that are probably involved in the binding of water molecules. Generally, many physical properties such as colour, texture and firmness partly depend on the water holding capacity (WHC) of a given food material [20].

\subsection{Changes in Colour Attributes during Iced Storage}

Colour is a well-known attribute relevant for consumer evaluation of quality of seafood. To understand the colour variations that occur during the processing of seafood is therefore imperative [22]. In a recent study that assessed the quality and shelf life of untreated Pacific white shrimp stored on ice, the colour attributes with respect to both metric chroma and total colour differences were reported, which focused on a holistic quality description of colour and therefore did not consider the individual $L^{*}, a^{*}$, and $b^{*}$ colour parameters [2]. Metric chroma describes the correlate of saturation as well as measure of vividness of colour whereas the total colour differences 


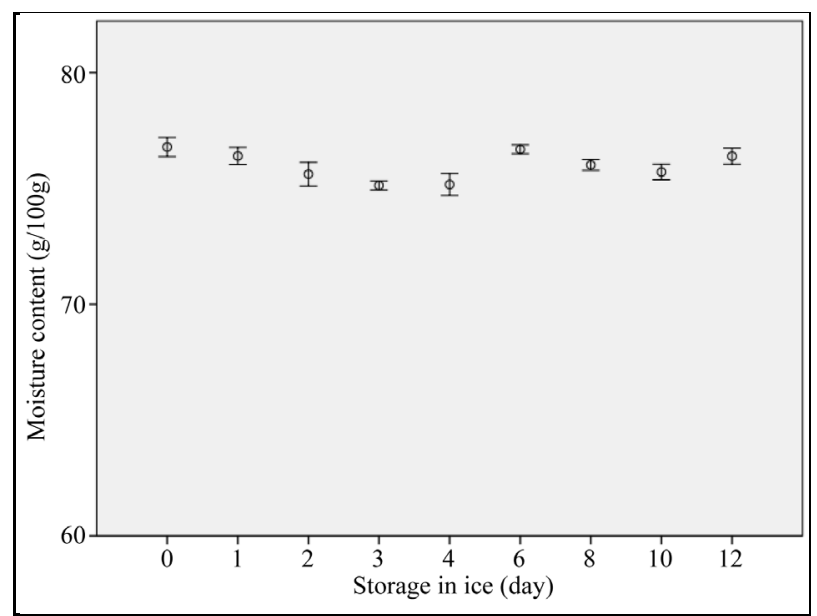

(a)

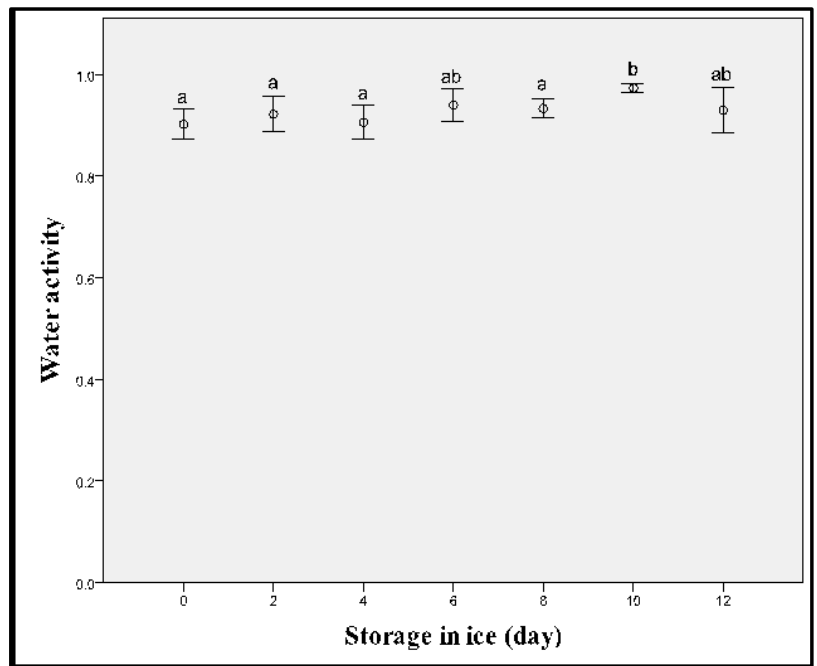

(b)

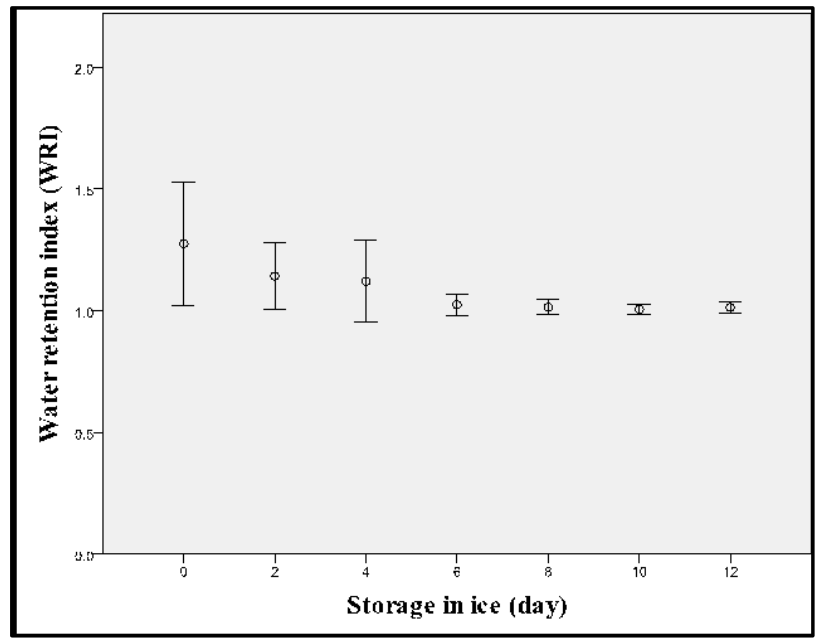

(c)

Figure 6. (a)-(c) Changes in (a) moisture content, (b) water activity $\left(a_{w}\right)$, and (c) water retention index (WRI) of Pacific white shrimp during 12 days of iced storage. In Figure 6(b), different letters indicate significant difference $(P<0.05)$. Bars represent standard deviations $(n=3)$. 
(TCD) indicate the magnitude of colour changes [2] [45] [46]. Notably, Schubring [47] was convinced that the action of freezing could contribute to influence the overall colour change in the brown shrimp. Given that researchers like Du and Sun [48] highlighted that colour could be among essential parameters that determine quality attributes of foods, to comprehend how iced storage would impact on the individual $L^{*}, a^{*}$ and $b^{*}$ colour indices of untreated Pacific white shrimp is crucial and this was undertaken in the present work.

During iced storage, there were significant differences in lightness $\left(L^{*}\right)$ of $L$. vannamei shrimp $(P<0.05)$. Specifically from day 2 the lightness remained unchanged up to day $8(P>0.05)$ and would increase up to a peak $(42.27 \pm 4.39)$ at day 10 after which a decline is shown $(P<0.05)$ (Figure 7(a)). The increases as well as the peak of lightness of shrimp obtained at day 10 of the present investigation seem to be in agreement with the previous observations of Okpala et al. [2] that reported increases in metric chroma and total colour differences (TCD) of untreated Pacific white shrimp during iced storage. The authors also understood that the colour of shrimp would increase in both magnitude and vividness particularly during the later part of iced storage. Their observation however seems not to agree with the colour data reported by Huidobro et al. [23] with respect to pink shrimp (Parapenaeus longirostris) that were processed on-board under iced storage conditions. Through sensory evaluation, Huidobro et al. [23] recognised the maximum initial colour score to shrimp chilled with flake ice and recognised the lower score to that subjected to liquid ice, considering the much less characteristic colours amidst the more brightness colours. Furthermore, the sensory assessors detected a fair increase in whiteness of shrimp and suggested that it may have decreased the colour quality, coincidental with loss of pink colour of the measured shrimp sample at that study. The authors further suggested that, perchance the colour observations were to be holistically considered, it could contribute to depreciate the commercial value of shrimp product.

Concerning $a^{*}$ colour value, no significant difference with iced storage was observed $(P>0.05)$ (Figure 7(b)). Concerning yellowness $\left(b^{*}\right)$ colour value and particularly during the initial 6 days of storage, no significant difference was observed $(P>0.05)$. It was after day 6 that the $b^{*}$ colour significantly increased up to a peak $(8.43 \pm 1.31)$ by day 10 and thereafter, it decreased noticeably $(P<0.05)$ (Figure $7(\mathrm{c}))$. The significant increase in yellowness $\left(b^{*}\right)$ observed for the untreated shrimp with iced storage reflects a colur shift, from somewhat red to a more yellow appearance. Probably, this might have occurred due to fair breakdown of astaxanthin, which might attribute to partial up to high pressure exerted by presence of oxygen [49]-[51].

Generally, the colour of shrimp has been associated with certain groups of carotenoids, such as astaxanthin, canthaxanthin, $\beta$-carotene and xanthophylls. Essentially, the astaxanthin is suggested to have much influence on the total carotenoids of shrimp [19] [52]. In the present study, the $L^{*}, a^{*}$ and $b^{*}$ colour values had relatively large standard deviations, which might possibly suggest an uneven washing-out of colour during iced storage. Also worth considering at the present study is that the shrimp were not homogenised prior to the colour determinations. Other contributing factors that could influence the colour of shrimp have been reported, for example, the natural pigment variations with different parts of black tiger (Penaeus monodon) as well as white (Penaeus vannamei) shrimp meat was shown to influence the differences in $L^{*}, a^{*}$ and $b^{*}$ colour scales with iced storage [53].

\subsection{Changes in Texture Attributes during Iced Storage}

Hardness refers to work done to achieve peak force at the first compression of force-time in a typical texture analysis profile [54]. Adhesiveness refers to the combination of both adhesive and cohesive force [55]. The texture of fish flesh could be influenced by a number of factors, such as the age, distribution of muscle lipids, fat content, feeding management, fish species, as well as handling stress prior slaughter [56]. In the present study, the ANOVA test indicated no noticeable difference in the adhesiveness (Figure 8(a)) and hardness (Figure 8(b)) textures of $L$. vannamei shrimp during iced storage $(P>0.05)$ even though both texture attributes revealed peak values particularly at day 11 . The peak values might suggest the shrimp to be less marketable at later stages of iced storage - a possible and quick signal by retailers/sellers to check the physical condition of shrimp. While investigating thawed white shrimp, Diaz-Tenorio and colleagues suggested that the differences in protein structure of shrimp could be associated with the differences in hardness during processing, which might possibly contribute to affect and define other characteristic properties as well as the overall consumer acceptability [57]. However, in agreement with the present study, the deep water pink shrimp investigated by Huidobro et al. [23] that found differences in hardness and elasticity during iced storage, particularly suggested that ice might have the potential to affect the myofibrillar protein to bring about an immediate up to intense contractions of muscle of the shrimp meat. 


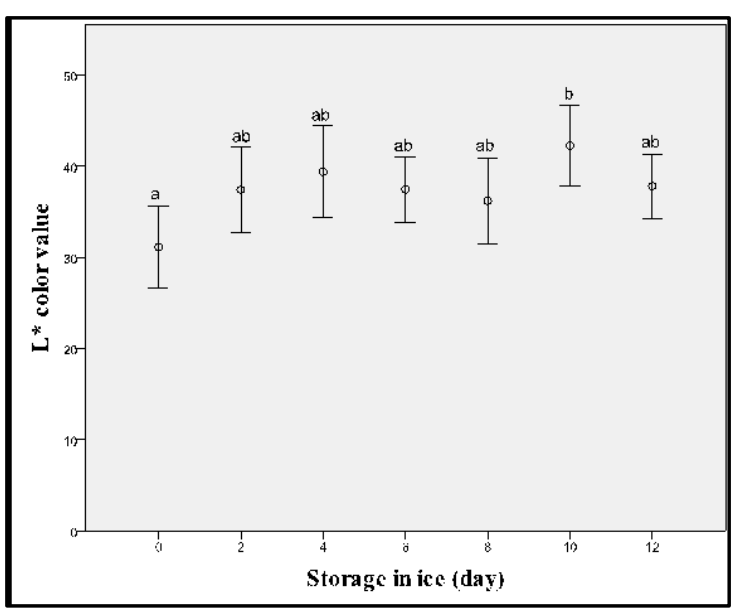

(a)

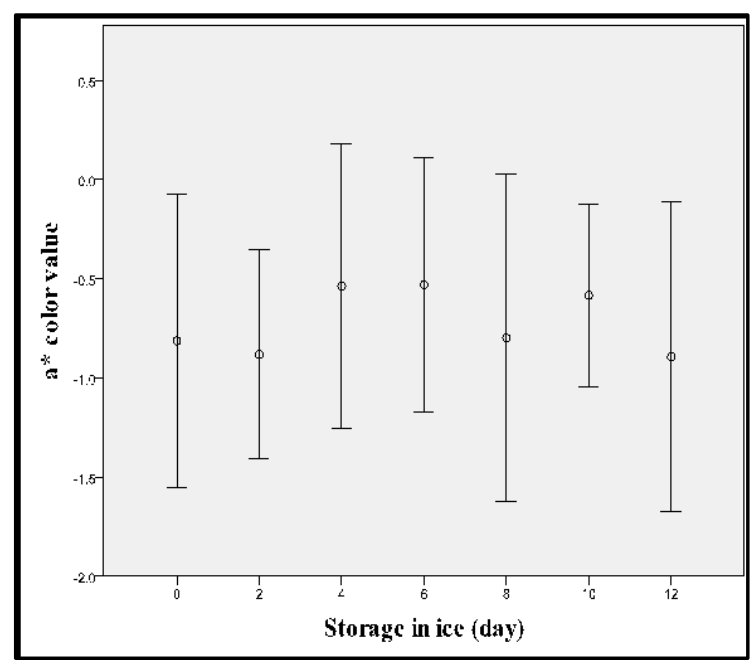

(b)

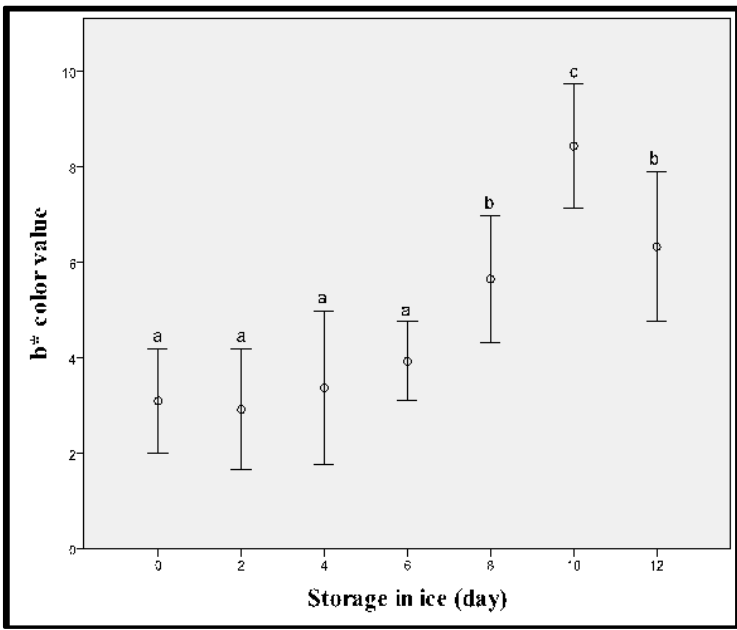

(c)

Figure 7. (a)-(c) Changes in (a) $L^{*}$, (b) $a^{*}$, and (c) $b^{*}$ colour values of Pacific white shrimp during 12 days of iced storage. In Figure 6(a) and Figure 6(c), different letters indicate significant difference $(P<0.05)$. Bars represent standard deviations $(n=3)$. 


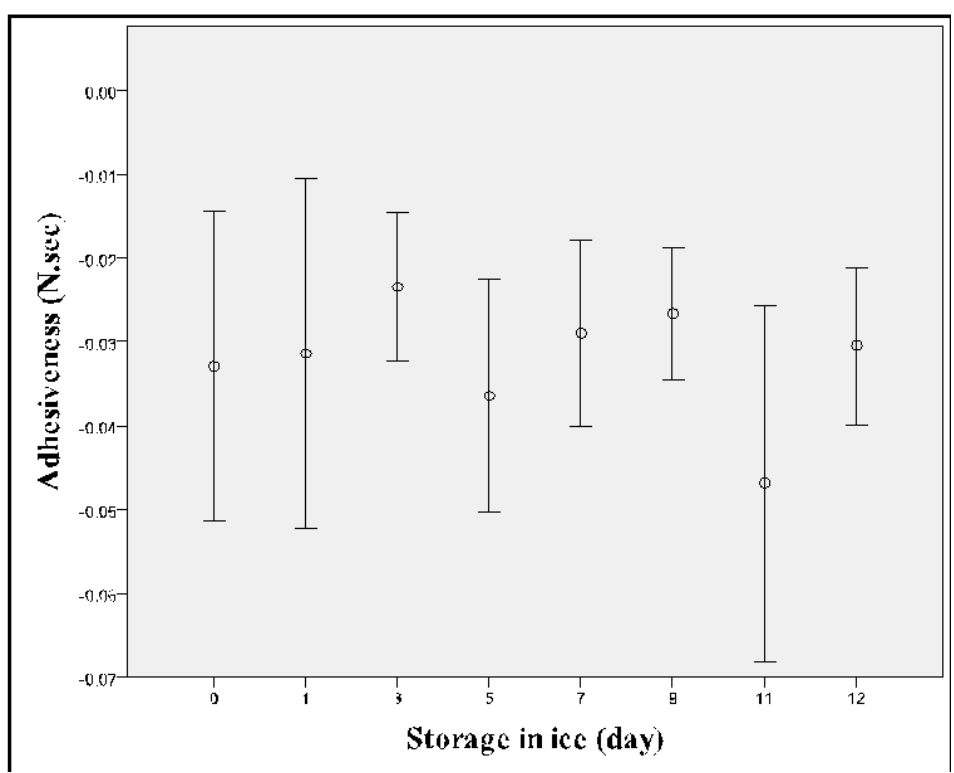

(a)

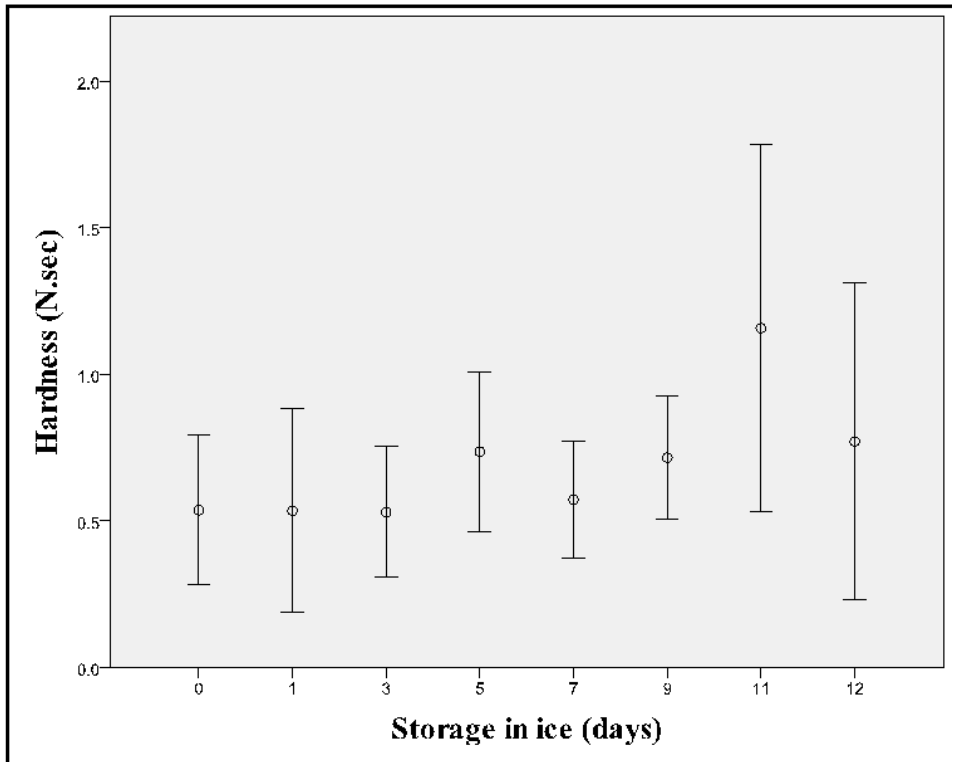

(b)

Figure 8. (a) (b) Changes in (a) adhesiveness and (b) hardness textures of Pacific white shrimp during 12 days of iced storage. Bars represent standard deviations $(n=3)$.

\section{Conclusion}

The physico-chemical changes of farm-raised untreated Pacific white shrimp as influenced by iced storage were investigated. The results indicated that the iced storage contributed significantly to the physico-chemical changes of farm-raised shrimp. Across the three farms investigated, the proximal composition, pH, colour and texture parameters of freshly harvested shrimp between the three farms showed marginal differences. With ice storage however, $\mathrm{pH}$ appreciably increased with slight differences in fat and protein contents. In addition, the moisture, $a_{w}$ and WRI values showed inconsequential changes. The peak $L^{*}$ and $b^{*}$ colour as well as the hardness and adhesiveness values respectively obtained at days 10 and 11 and might suggest the shrimp less marketable at later stages of iced storage, which can possibly serve as quick signal for retailers/sellers regarding the 
possible decline of the quality condition of shrimp. In addition to this work, a recent baseline investigation showed that biometrics and physicochemical attributes of freshly harvested L. vannamei shrimp do not correlate, but could do so independently [58]. Overall, the physicochemical differences in farm-raised shrimp during iced storage provide valuable information for the shrimp industry. Importantly, the data provided at this study can serve as baseline for useful comparison and evaluation of preservative treatments applied to shrimp.

\section{Acknowledgements}

Monash University Sunway Campus-Malaysia, funded this research. Author is grateful to laboratory staff of School of Science for logistical support during the research investigation.

\section{References}

[1] Manheem, K., Benjakul, S., Kijroongrojana, K. and Visessanguan, W. (2012) The Effect of Heating Conditions on Polyphenol Oxidase, Proteases and Melanosis in Pre-Cooked Pacific White Shrimp during Refrigerated Storage. Food Chemistry, 131, 1370-1375. http://dx.doi.org/10.1016/j.foodchem.2011.10.001

[2] Okpala, C.O.R., Choo, W.S. and Dykes, G.A. (2014) Quality and Shelf Life Assessment of Pacific White Shrimp (Litopenaeus vannamei) Freshly Harvested and Stored on Ice. LWT_Food Science and Technology, 55, 110-116. http://dx.doi.org/10.1016/j.lwt.2013.07.020

[3] Okpala, C.O.R. (2014) Investigation of Quality Attributes of Ice-Stored Pacific White Shrimp (Litopenaeus vannamei) as Affected by Sequential Minimal Ozone Treatment. LWT_Food Science and Technology, 57, 538-547. http://dx.doi.org/10.1016/j.lwt.2014.02.007

[4] Okpala, C.O.R. (2014) Changes of Physico-Chemical Properties of Sequential Minimal Ozone-Treated Ice-Stored Pacific White Shrimp (Litopenaeus vannamei). Current Nutrition and Food Sciences, 10, 218-227. http://dx.doi.org/10.2174/1573401310666140306003557

[5] Okpala, C.O.R. (2015) Quality Evaluation and Shelf Life of Minimal Ozone-Treated Pacific White Shrimp (Litopenaeus vannamei) Stored on Ice. Journal für Verbraucherschutz und Lebensmittelsicherheit, 10, 49-57. http://dx.doi.org/10.1007/s00003-014-0904-x

[6] Okpala, C.O.R. (2015) Ice Induced Physicochemical and Microbiological Changes in Pacific White Shrimp. Proceedings of Actes du Séminaire International sur les Sciences Alimentaires (SISA), Les 14, 15 and 16 Octobre 2014, Instiute de la Nutrition de l'Alimentation et des Technologies Agro-Alimentaires (INATAA), Université Constantine 1, Algérie, Abstract P-116, p. 113.

[7] FAO (2009) Online Query Panel: Global Aquaculture Production 1950-2007. Food and Agriculture Organization of the United Nations, Fisheries and Aquaculture Department. Accessed April 2009. http://www.fao.org/fishery/statistics/global-aquaculture-production/query/en

[8] Ma, Z., Wan, R., Song, X. and Gao, L. (2013) The Effect of Three Culture Methods on Intensive Culture System of Pacific White Shrimp (Litopenaeus vannamei). Journal of Ocean University of China, 12, 434-440. http://dx.doi.org/10.1007/s11802-013-2321-7

[9] Ramirez-Guerra, H.E., Garcia-Sifuentes, C.O., Pacheco-Aguilar, R., Ramirez-Suarez, J.C., Lugo-Sanchez, M.E. and Scheuren-Acevedo, S.M. (2012) The Influence of Ante-Mortem Hypoxia on the Physicochemical Stability of Myofibrillar Proteins in the Muscle Tissue of White Shrimp (Litopenaeus vannamei) Exposed to Multiple Freeze-Thaw Cycles. European Food Research and Technology, 235, 37-45. http://dx.doi.org/10.1007/s00217-012-1702-2

[10] Vatana, P. and Del Rosario, R.R. (1983) Biochemical Changes in Fermented Rice-Shrimp (Macrobrachium idella) Mixture: Changes in Protein Fractions. Food Chemistry, 12, 33-43. http://dx.doi.org/10.1016/0308-8146(83)90048-1

[11] Boonsumrej, S., Chaiwanichsiri, S., Tantratian, S., Suzuki, T. and Takai, R. (2007) Effects of Freezing and Thawing on the Quality Changes of Tiger Shrimp (Penaeus monodon) Frozen by Air-Blast and Cryogenic Freezing. Journal of Food Engineering, 80, 292-299. http://dx.doi.org/10.1016/j.jfoodeng.2006.04.059

[12] Nirmal, N.P. and Benjakul, S. (2009) Melanosis and Quality Changes of Pacific White Shrimp (Litopenaeus vannamei) Treated with Catechin during Iced Storage. Journal of Agricultural and Food Chemistry, 57, 3578-3586. http://dx.doi.org/10.1021/jf900051e

[13] Nirmal, N.P. and Benjakul, S. (2012) Inhibition Kinetics of Catechin and Ferulic Acid on Polyphenoloxidase from Cephalothorax of Pacific White Shrimp (Litopenaeus vannamei). Food Chemistry, 131, 569-573. http://dx.doi.org/10.1016/j.foodchem.2011.09.025

[14] Essien, E.U. (1995) Lipid Content and Fatty Acid Profiles of Some Lesser Known Nigerian Foods. Journal of Food Biochemistry, 19, 153-159. http://dx.doi.org/10.1111/j.1745-4514.1995.tb00528.x 
[15] Fatima, R., Khan, M.A. and Qadri, R.B. (1988) Shelf-Life of Shrimp (Penaeus merguiensis) Stored in Ice $\left(0^{\circ} \mathrm{C}\right)$ and Partially Frozen $\left(-3^{\circ} \mathrm{C}\right)$. Journal of the Science of Food and Agriculture, 42, 235-247. http://dx.doi.org/10.1002/jsfa.2740420306

[16] Huidobro, A., Mendes, R. and Nunes, M.L. (2001) Slaughtering of Gilthead Seabream (Sparus aurata) in Liquid Ice: Influence on Fish Quality. European Food Research and Technology, 213, 267-272. http://dx.doi.org/10.1007/s002170100378

[17] Sadok, S., Abdelmoulah, A. and El Abed, A. (2004) Combined Effect of Sepia Soaking and Temperature on the Shelf Life of Peeled Shrimp Penaeus kerathurus. Food Chemistry, 88, 115-122. http://dx.doi.org/10.1016/j.foodchem.2003.12.031

[18] Ozden, O. (2005) Changes in Amino Acid and Fatty Acid Composition during Shelf-Life of Marinated Fish. Journal of the Science of Food and Agriculture, 85, 2015-2020. http://dx.doi.org/10.1002/jsfa.2207

[19] Niamnuy, C., Devahastin, S. and Soponronnarit, S. (2008) Changes in Protein Compositions and Their Effects on Physical Changes of Shrimp during Boiling in Salt Solution. Food Chemistry, 108, 165-175. http://dx.doi.org/10.1016/j.foodchem.2007.10.058

[20] Rawdkuen, S., Jaimakreu, M. and Benjakul, S. (2013) Physicochemical Properties and Tenderness of Meat Samples Using Proteolytic Extract from Calotropis procera Latex. Food Chemistry, 136, 909-916. http://dx.doi.org/10.1016/j.foodchem.2012.08.077

[21] Lin, K.W. and Chao, J.Y. (2001) Quality Characteristics of Reduced-Fat Chinese-Style Sausage as Related to Chitosan’s Molecular Weight. Meat Science, 59, 343-351. http://dx.doi.org/10.1016/S0309-1740(01)00084-5

[22] Mathiassen, J.R., Misimi, E., Bondo, M., Veliyulin, E. and Ostvik, S.O. (2011) Trends in Application of Imaging Technologies to Inspection of Fish and Fish Products. Trends in Food Science \& Technology, 22, 257-275. http://dx.doi.org/10.1016/j.tifs.2011.03.006

[23] Huidobro, A., Lopez-Caballero, M.E. and Mendes, R. (2002) Onboard Processing of Deepwater Pink Shrimp (Parapenaeus longirostris) with Liquid Ice: Effect on Quality. European Food Research and Technology, 214, 469-475. http://dx.doi.org/10.1007/s00217-002-0490-5

[24] Venugopal, V. (2006) Seafood Processing: Adding Value through Quick Freezing, Retortable Packaging, and CookChilling. Tayor and Francis Group, Florida, 504.

[25] Kirk, R.S. and Sawyer, R. (1991) Pearson’s Composition and Analysis of Foods. Longman Group UK Limited, London.

[26] AOAC (2011) Official Methods of Analysis of AOAC International. 18th Edition, AOAC International, Gaitherburg, 2590.

[27] Arfat, Y. and Benjakul, S. (2012) Gelling Characteristics of Surimi from Yellow Stripe Trevally (Selaroides leptolepis). International Aquatic Research, 4, 1-3. http://dx.doi.org/10.1186/2008-6970-4-5

[28] Schanda, J. (2007) Colorimetry: Understanding the CIE System. John Wiley \& Sons Inc., Hoboken, 467. http://dx.doi.org/10.1002/9780470175637

[29] Lin, K.W. and Keeton, J.T. (1998) Textural and Physicochemical Properties of Low-Fat, Pre-Cooked Ground Beef Patties Containing Carageenan and Sodium Alginate. Journal of Food Science, 63, 571-574. http://dx.doi.org/10.1111/j.1365-2621.1998.tb15787.x

[30] Bourne, M.C. (2002) Food Texture and Viscosity: Concept and Measurement. 2nd Edition, Academic Press, San Diego. http://dx.doi.org/10.1016/b978-012119062-0/50001-2

[31] Okpala, C.O.R. (2010) High Pressure Processing of Fresh Cheese. Lambert Academic Publishing, Saarbrücken, 104.

[32] Okpala, C.O.R., Piggott, J.R. and Schaschke, C.J. (2010) Influence of High-Pressure Processing (HPP) on Physico-Chemical Properties of Fresh Cheese. Innovative Food Science and Emerging Technologies, 11, 61-67. http://dx.doi.org/10.1016/j.ifset.2009.10.003

[33] Sriket, C., Benjakul, S., Visessanguan, W. and Kijroongrojana, K. (2007) Comparative Studies on Chemical Composition and Thermal Properties of Black Tiger Shrimp (Penaeus monodon) and White Shrimp (Penaeus vannamei) Meats. Food Chemistry, 103, 1199-1207. http://dx.doi.org/10.1016/j.foodchem.2006.10.039

[34] Cao, W., Zhang, C., Hong, P., Ji, H., Hao, J. and Zhang, J. (2009) Autolysis of Shrimp Head by Gradual Temperature and Nutritional Quality of the Resulting Hydrolysate. LWT-Food Science and Technology, 42, 244-249. http://dx.doi.org/10.1016/j.lwt.2008.05.026

[35] Chaijan, M. (2011) Physicochemical Changes of Tilapia (Oreochromis niloticus) Muscle during Salting. Food Chemistry, 129, 1201-1210. http://dx.doi.org/10.1016/j.foodchem.2011.05.110

[36] Ozogul, Y., Ozyurt, G., Ozogul, F., Kuley, E. and Polat, A. (2005) Freshness Assessment of European Eel (Anguilla anguilla) by Sensory, Chemical and Microbiological Methods. Food Chemistry, 92, 745-751. http://dx.doi.org/10.1016/j.foodchem.2004.08.035 
[37] Mu, H., Chen, H., Fang, X., Mao, J. and Gao, H. (2012) Effect of Cinnamaldehyde on Melanosis and Spoilage of Pacific White Shrimp (Litopenaeus vannamei) during Storage. Journal of the Science of Food and Agriculture, 92, 21772182. http://dx.doi.org/10.1002/jsfa.5605

[38] Eid, N., Dashti, B. and Sawaya, W. (1992) Chemical and Physical Characterization of Shrimp By-Catch of the Arabian Gulf. Food Research International, 25, 181-186. http://dx.doi.org/10.1016/0963-9969(92)90135-R

[39] Tsironi, T., Dermesonlouoglou, E., Giannakourou, M. and Taoukis, P. (2009) Shelf Life Modelling of Frozen Shrimp at Variable Temperature Conditions. LWT_Food Science and Technology, 42, 664-671. http://dx.doi.org/10.1016/j.lwt.2008.07.010

[40] Erkan, N., Tosun, S.Y., Ulusoy, S. and Uretener, G. (2011) The Use of Thyme and Laurel Essential Oil Treatments to Extend the Shelf Life or Bluefish (Pomatomus saltatrix) during Ice Storage. Journal fur Verbraucherschutz und Lebensmittelsicherheit, 6, 39-48. http://dx.doi.org/10.1007/s00003-010-0587-X

[41] Finne, G. (1979) Enzymatic Ammonia Production in Penaied Shrimp Held on Ice. Abstracts of Papers of the American Chemical Society (SEP), 25-25.

[42] Lopez-Caballero, M.E., Martinez-Alvarez, O., Gomez-Guillen, M.D. and Montero, P. (2007) Quality of Thawed Deepwater Pink Shrimp (Parapenaeus longirostris) Treated with Melanosis-Inhibiting Formulations during Chilled Storage. International Journal of Food Science and Technology, 42, 1029-1038. http://dx.doi.org/10.1111/j.1365-2621.2006.01328.x

[43] Nielsen, S.S. (2010) Food Analysis. 4th Edition, Food Science Text Series, Springer, USA, 602. http://dx.doi.org/10.1007/978-1-4419-1478-1

[44] Richardson, T. and Finley, J.W. (Eds.) (1986) Chemical Changes in Food during Processing. 1st Edition, IFT Basic Symposium Series, Van Nostrand Reinhold Company Inc., New York, 520. http://dx.doi.org/10.1007/978-1-4613-2265-8

[45] Cruz-Romero, M., Kelly, A.L. and Kerry, J.P. (2007) Effects of High-Pressure and Heat Treatments on Physical and Biochemical Characteristics of Oysters (Crassostrea gigas). Innovative Food Science and Emerging Technologies, 8, 30-38. http://dx.doi.org/10.1016/j.ifset.2006.05.002

[46] Cortes, C., Esteve, M.J. and Frigola, A. (2008) Color of Orange Juice Treated by High Intensity Pulsed Electric Fields during Refrigerated Storage and Comparison with Pasteurised Juice. Food Control, 19, 151-158. http://dx.doi.org/10.1016/j.foodcont.2007.03.001

[47] Schubring, R. (2002) Influence of Freezing/Thawing and Frozen Storage on the Texture and Colour of Brown Shrimp (Crangon crangon). Archiv fur Lebensmittelhygiene, 53, 34-36.

[48] Du, C.J. and Sun, D.W. (2011) Retrospective Shading Correlation of Confocal Laser Scanning Microscopy Beef Images for Three Dimentional Visualisation. Food and Bioprocess Technology, 2, 167-176. http://dx.doi.org/10.1007/s11947-007-0032-z

[49] Christophersen, A.G., Jun, H., Jorgensen, K. and Skibsted, L.H. (1991) Photobleaching of Astaxanthin and Canthaxanthin-Quantum-Yields Dependence of Solvent, Temperature, and Wavelength of Irradiation in Relation to Packaging and Storage of Carotenoid Pigmented Salmonoids. Zeitschrift Fur Lebensmittel-Untersuchung Und-Forschung, 192, 433-439. http://dx.doi.org/10.1007/BF01193143

[50] Nielsen, B.R., Mortensen, A., Jorgensen, K. and Skibsted, L.H. (1996) Singlet versus Triplet Reactivity in Photodegradation of C-40 Carotenoids. Journal of Agricultural and Food Chemistry, 44, 2106-2113. http://dx.doi.org/10.1021/jf9508007

[51] Bak, L.S., Andersen, A.B., Andersen, E.M. and Bertelsen, G. (1999) Effect of Modified Atmosphere Packaging on Oxidative Changes in Frozen Stored Cold Water Shrimp (Pandalus borealis). Food Chemistry, 64, 169-175. http://dx.doi.org/10.1016/S0308-8146(98)00152-6

[52] Latscha, T. (1989) The Role of Astaxanthin in Shrimp Pigmentation. Advances in Tropical Aquaculture, Aquacop Ifremer Actes de Collegue, 9, 319-325.

[53] Benjakul, S., Visessanguan, W., Kijroongrojana, K. and Sriket, P. (2008) Effect of Heating on Physical Properties and Microstructure of Black Tiger Shrimp (Penaeus monodon) and White Shrimp (Penaeus vannamei) Meats. International Journal of Food Science and Technology, 43, 1066-1072. http://dx.doi.org/10.1111/j.1365-2621.2007.01566.x

[54] Chen, J. (2009) Food Oral Processing-A Review. Food Hydrocolloids, 23, 1-25. http://dx.doi.org/10.1016/j.foodhyd.2007.11.013

[55] Aday, M.S. and Caner, C. (2013) The Shelf Life Extension of Fresh Strawberries Using an Oxygen Absorber in the Biobased Package. LWT_Food Science and Technology, 52, 102-109. http://dx.doi.org/10.1016/j.lwt.2012.06.006

[56] Saez, M.I., Navarro, G., Garcia-Mesa, S., Martinez, T.F., Garcia-Gallego, M. and Suarez, M.D. (2013) Influence of Pre-Slaughtering Feed Restriction on Muscle Characteristics of Farmed Sea Bass (Dicentrarchus labrax L.) during Cold Storage. Journal of the Science of Food and Agriculture, 93, 2323-2330. http://dx.doi.org/10.1002/jsfa.6048 
[57] Diaz-Tenorio, L.M., Garcia-Carreno, F.L. and Pacheco-Aguilar, R. (2007) Comparison of Freezing and Thawing Treatments on Muscle Properties of Whiteleg Shrimp (Litopenaeus vannamei). Journal of Food Biochemistry, 31, 563-576. http://dx.doi.org/10.1111/j.1745-4514.2007.00130.x

[58] Okpala, C.O.R. and Bono, G. (2015) Investigating the Biometric and Physicochemical Characteristics of Freshly Harvested Pacific White Shrimp (Litopenaeus vannamei): A Comparative Approach. Journal of the Science of Food and Agriculture. (in press) 